\section{Induction of seed coat water impermeability during maturation of Erythrina speciosa seeds}

\author{
Debora Manzano Molizane $^{1}$ (D), Sandra Maria Carmello-Guerreiro² ${ }^{(D)}$, Claudio \\ José Barbedo ${ }^{3 *}$ (iD)
}

ABSTRACT: Dormancy is a physiological process that allows seeds to survive in unfavorable environments by preventing their germination. For a large number of species, seed desiccation at the end of maturation is common, and for some of these seeds, this includes seed coat water impermeability (SCWI). The environmental conditions in which the mother plant develops affect the seed maturation process, causing variations in both seed physiological quality and the onset of physical dormancy. In this study, we analyzed the induction of SCWI in immature seeds of Erythrina speciosa by artificial drying. Seeds at three stages of immaturity were dried gradually for subsequent evaluation of their germination. At each level of drying, the anatomical structure of the seed coat was also analyzed. Artificial drying was able to induce SCWI in immature seeds. Furthermore, environmental conditions affected at which stage of maturity SCWI began, and they affected development of desiccation tolerance. However, unlike other species, there were no anatomical differences related to this SCWI (whether by natural drying or artificial drying) and, therefore, in $E$. speciosa seeds, SCWI may be related to biochemical differences in the seed coat.

Index terms: dormancy, drying, desiccation tolerance, tropical tree species.

Indução da impermeabilidade do tegumento em relação a água durante a maturação em sementes de Erythrina speciosa

RESUMO: A dormência é um processo fisiológico que permite que as sementes sobrevivam em ambientes desfavoráveis, impedindo sua germinação. Para grande número de espécies, a dessecação de sementes no final da maturação é comum e, em algumas delas, instalase a impermeabilidade do tegumento à água (IT). As condições ambientais sob as quais a planta-mãe se desenvolve interferem no processo de maturação das sementes, causando variações tanto na qualidade fisiológica quanto na instalação da dormência física. Neste trabalho analisou-se a instalação de IT em sementes imaturas de Erythrina speciosa por secagem artificial. Sementes de três estádios imaturos foram secadas em intervalos graduais e sua germinação foi analisada. $O$ tegumento das sementes de cada nível de secagem também foi analisado anatomicamente. Concluiu-se que a secagem artificial foi capaz de promover a instalação da IT em sementes imaturas. Além disso, as condições ambientais influenciaram o estádio de maturidade no qual a IT foi instalada, bem como o desenvolvimento da tolerância à dessecação. No entanto, diferente de outras espécies, não houve diferenças anatômicas relacionadas a essa IT (tanto pela secagem natural quanto pela artificial) e, portanto, em sementes de E. speciosa, a impermeabilidade pode estar relacionada a diferenças bioquímicas no tegumento da semente.

Termos para indexação: dormência, secagem, tolerância à dessecação, espécie arbórea tropical.
Journal of Seed Science, v.42, e202042020, 2020

http://dx.doi.org/10.1590/ 2317-1545v42228614
${ }^{*}$ Corresponding author
E-mail: cjbarbedo@yahoo.com.br

Received: $12 / 09 / 2019$

Accepted: 27/02/2020.

${ }^{1}$ Instituto de Biociências (UNESP), Caixa Postal 510, 18618-970 Botucatu, SP, Brasil.

${ }^{2}$ Instituto de Biologia (UNICAMP), 13083-862 - Campinas, SP, Brasil.

${ }^{3}$ Instituto de Botânica, Núcleo de Pesquisa em Sementes, 04301-902 São Paulo, SP, Brasil. 


\section{INTRODUCTION}

Dormancy is a physiological process that allows seeds to survive in adverse environments by preventing immediate and/or synchronized germination, thus allowing temporal dispersion of the seeds. Among the various types of dormancy, physical dormancy, imposed by impermeability of the seed coat to water, is commonly found in Fabaceae. Seeds often exhibit dormancy by impermeability of the seed coat to water (SCWI) at the end of the maturation process, and this impermeability may be triggered by desiccation (Baskin and Baskin, 2000; Jayasuriya et al., 2007a, 2007b; Nakagawa et al., 2007).

The environmental conditions that the mother plant is exposed to during the seed maturation process can affect the induction of physical dormancy. Thus, seeds of the same species can exhibit considerable differences in regard to physical dormancy, both in relation to its intensity and to the time at which it is induced. These variations are frequently linked to environmental conditions and therefore depend on the location or year of production of the seeds (Hay et al., 2010; Gama-Arachchige et al., 2011; Lamarca et al., 2013). In Trifolium ambiguum seeds, for example, artificial drying led to the induction of physical dormancy in still immature seeds, simultaneous to the process of acquisition of desiccation tolerance. Immature seeds of Geranium carolinianum dried down to $11 \%$ moisture became dormant, while dormancy was not induced in those dried to 13\% (Hay et al., 2010; Gama-Arachchige et al., 2011). Therefore, the onset of dormancy represented by seed coat water impermeability may not necessarily be connected with completing the maturation process, but may occur as a result of natural drying at the end of maturation. Therefore, there is the need for more studies in this respect to understand the drying process and the onset of dormancy.

Erythrina speciosa Andrews (Leguminosae, Faboideae) has seeds that are tolerant to desiccation and can be stored for several years. When these seeds are mature, they frequently have a seed coat impermeable to water absorption (Mello et al., 2010; Lima and Martins, 2014). Thus, they are interesting materials for studying induction of dormancy in immature seeds. The aim of this study was to analyze the relationship between the impermeability of the testa of mature seeds of $E$. speciosa and the impermeability induced by artificial drying in immature seeds.

\section{MATERIALS AND METHODS}

Plant material: Erythrina speciosa fruit was collected from thirty mother plants in the Catavento Cultural Park in an urban area of the municipality of São Paulo, SP $\left(23^{\circ} 32^{\prime} 44^{\prime \prime}\right.$ S and $\left.46^{\circ} 37^{\prime} 40^{\prime \prime} \mathrm{W}\right)$ from August to October of 2013 and 2014. The fruit was broken and seeds were removed manually. These seeds were separated into three maturity stages according to their size and the morphological characteristics of the seed coat, seeking to follow the classification of Hell et al. (2019): Stage III (S3) - light green color with light brown spots, mean length of $1.6 \mathrm{~cm}$; Stage IV (S4) - green color and covered by brown spots, mean length of $1.88 \mathrm{~cm}$; Stage V (S5) - brown color with green spots, mean length of $1.52 \mathrm{~cm}$. That way, the following sets of seeds were obtained, according to maturity stage and year of collection: S3/2013, S3/2014, S4/2013, S4/2014, S5/2013, and S5/2014. Immediately after this separation, seeds from each stage, from each year, were analyzed regarding moisture content, dry matter content, and germination, as described below.

Physical and physiological analyses: moisture content and dry matter content of the seeds were evaluated by the gravimetric method in a laboratory oven at $103{ }^{\circ} \mathrm{C}$ for seventeen hours (Brasil, 2009) using four replications of five seeds, and the results were presented in percentage (moisture content, wet basis) and in mg.seed $^{-1}$ (dry matter content). The germination test was set up in rolls of paper previously moistened with water (2.5 times the weight of the paper) (Brasil, 2009) and placed in a germination room at $25^{\circ} \mathrm{C}$ and $70 \%$ relative humidity. Evaluations were carried out every two days over a period of thirty days, registering the number of seeds with primary root emergence with a size greater than or equal to $0.5 \mathrm{~cm}$ (for calculation of germination percentage).

Drying: seeds from each stage were dried in a forced air circulation laboratory oven at $40{ }^{\circ} \mathrm{C}$, reducing the initial moisture content of the seeds $(69 \%, 50 \%, 37 \%$ for S3, S4, S5, respectively, in $2013 ; 70 \%, 63 \%$, and $36 \%$ for S3, S4, and S5, respectively, in 2014) in gradual intervals (reduction of ca. $2.0 \%$ to $2.5 \% . h^{-1}$ ) up to six levels of drying (D1, D2, D3, 
D4, D5, and D6), aiming to reach $10 \%$ moisture intervals between the drying levels to finally arrive at only $7 \%$ moisture content. After each step of drying, the moisture content and germination were evaluated. The seeds that had an impermeable testa were then mechanically scarified with sandpaper for wood (number 60) and then tested once more for germination, as already described.

Anatomical analyses: the seed coat of the S3/2013, S4/2013, S4/2014, S5/2013, and S5/2014 seeds were analyzed anatomically. Samples were fixed in FAA70 (formalin, 37\% glacial acetic acid, 70\% ethanol - 1:1:8 v/v, Johansen, 1940) and stored in $70 \%$ ethanol, according to manufacturer's recommendations. The samples were embedded in plastic resin (Leica Historesin ${ }^{\circledR}$ ), cut in transversal sections with a disposable blade in a manual rotary microtome RM2245 (Leica ${ }^{\circledR}$ ) at a thickness of $7 \mu \mathrm{m}$, and stained with $0.05 \%$ toluidine blue (O'Brien et al., 1964). Slides were analyzed in an Olympus BX51 photomicroscope, obtaining images by a coupled Olympus DP71 camera, on the DPManager program, and the scales were obtained under the same conditions as the photomicrographs. From these images, detailed analyses were performed with the aid of the ImageJ program, measuring the following structures: height of each layer in the seed coat, i.e., palisade cells, hourglass cells, and parenchyma, as well as measurements of the thickness of the light line and cuticle.

Experimental design and statistical analysis: a completely randomized experimental design was used with four replications. Three replications for each treatment were made for the measurements in each structure of the testa. Analysis of variance ( $\mathrm{F}$ test) was performed on the data and the means were compared by the Tukey test at the level of $5 \%$ by the $R$ statistical program.

\section{RESULTS AND DISCUSSION}

The seeds from S3/2013 and S3/2014 initially had 70\% moisture (Figures 1 and 2). Drying brought these values to 7\% (S3/2013, Figure 1a) and 12\% (S3/2014, Figure 2a). In S4, the seeds from 2013 had 50\% moisture and, after the last drying period, reached $7 \%$ (Figure 1a); those from 2014, which initially had $60 \%$ moisture, arrived at $14 \%$ after the last drying (Figure 2a). In S5, the seed lots had similar initial moisture content, 38\% for 2013 and 36\% for 2014, and maximum drying brought moisture content to $7 \%$ (2013, Figure 1a) and 12\% (2014, Figure 2a).

In the S3/2013 set, the seeds became impermeable upon reaching 15\% moisture (D3 and D3sc, Figures 1a and 1b). The seeds of $\mathbf{S 4} / 2013$, for their part, already became impermeable upon reaching $31 \%$ moisture (D2 and D2sc, Figures 1a and 1b), but those of S5/2013 only became impermeable when they reached 7\% moisture (D3 and D3sc, Figures 1a and 1b). In the seeds of 2014, impermeability to water was established only in S5, when drying brought moisture content to $13 \%$ (Figures $1 \mathrm{a}$ and $1 \mathrm{~b}$ ). The seeds of S3/2014 had not yet developed desiccation tolerance; more than $50 \%$ of them lost viability when drying brought moisture content to $25 \%$, and all lost viability when moisture content was reduced to $12 \%$ (Figures $2 \mathrm{a}$ and $2 \mathrm{~b}$ ). The seeds of S4/2014 did not become impermeable even when their moisture content was reduced to $14 \%$ (Figures $2 \mathrm{a}$ and $2 \mathrm{~b}$ ). However, it is probable that impermeability to water was developing in these seeds because, in addition to showing a small reduction in germination percentage (Figure $2 \mathrm{~b}$ ), this germination was delayed, as shown by the mean time for germination (Figure $2 \mathrm{c}$ ).

The E. speciosa seeds did not exhibit anatomical structural changes in the testa during drying of the immature stages, since the same structures present in the mature seeds (cuticle, palisade cells, light line, hourglass cells, and parenchyma) were present in the immature seeds (Figures 3 and 4). Differences were observed only in the tickness measurements of the layers in the testa (Figure 5) in S4 of 2013 and of 2014, as for example, the hourglass cells and also palisade cells, but without a clear relationship with drying, since neither layer exhibited a decrease in the measurements in accordance with drying. The differences in thickness of the light line and of the cuticle (Figures $5 c$ and $5 d$ ) also did not exhibit a relationship to drying. The tickness of the hourglass cells (Figures $5 e$ and $5 f$ ) of S4/2013 was the only one that exhibited results related to drying. The measurement observed for the palisade cells (Figure 5a) was near $100 \mu \mathrm{m}$ for both years of collection, while the parenchyma cells were between 50 and $200 \mu \mathrm{m}$ for the collection of 2013, and between 50 and $100 \mu \mathrm{m}$ for the collection of 2014. The cuticle had measurements ranging from 1 to $2.5 \mu \mathrm{m}$ for the collection of 2013 and from 1 to $2 \mu \mathrm{m}$ for 2014. The hourglass cells, for their part, ranged from 10 to $33 \mu \mathrm{m}$ for the 2013 collection, and from 8 to $18 \mu \mathrm{m}$ for 2014 . 

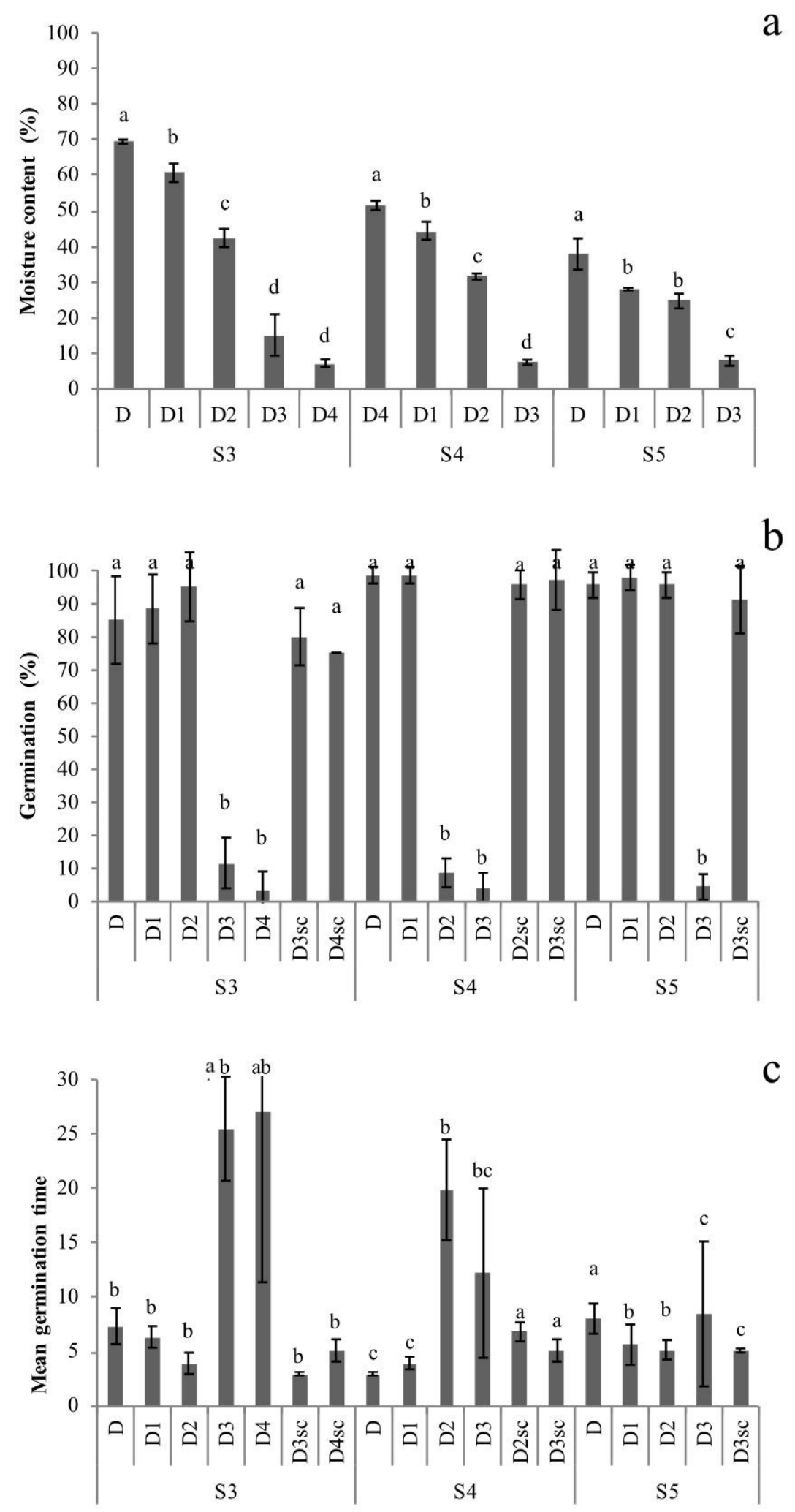

Columns with the same letter within each maturity stage represent values that do not differ from each other by the Tukey test (5\%).

D2sc, D3sc, and D4sc: scarified seeds; D: intact seeds.

Figure 1. Moisture content (a), germination (b), and mean germination time (c) of immature seeds of Stage 3 (S3), Stage 4 (S4), and Stage 5 (S5) of Erythrina speciosa collected in 2013 under four levels of drying (D1, D2, D3, and D4). 

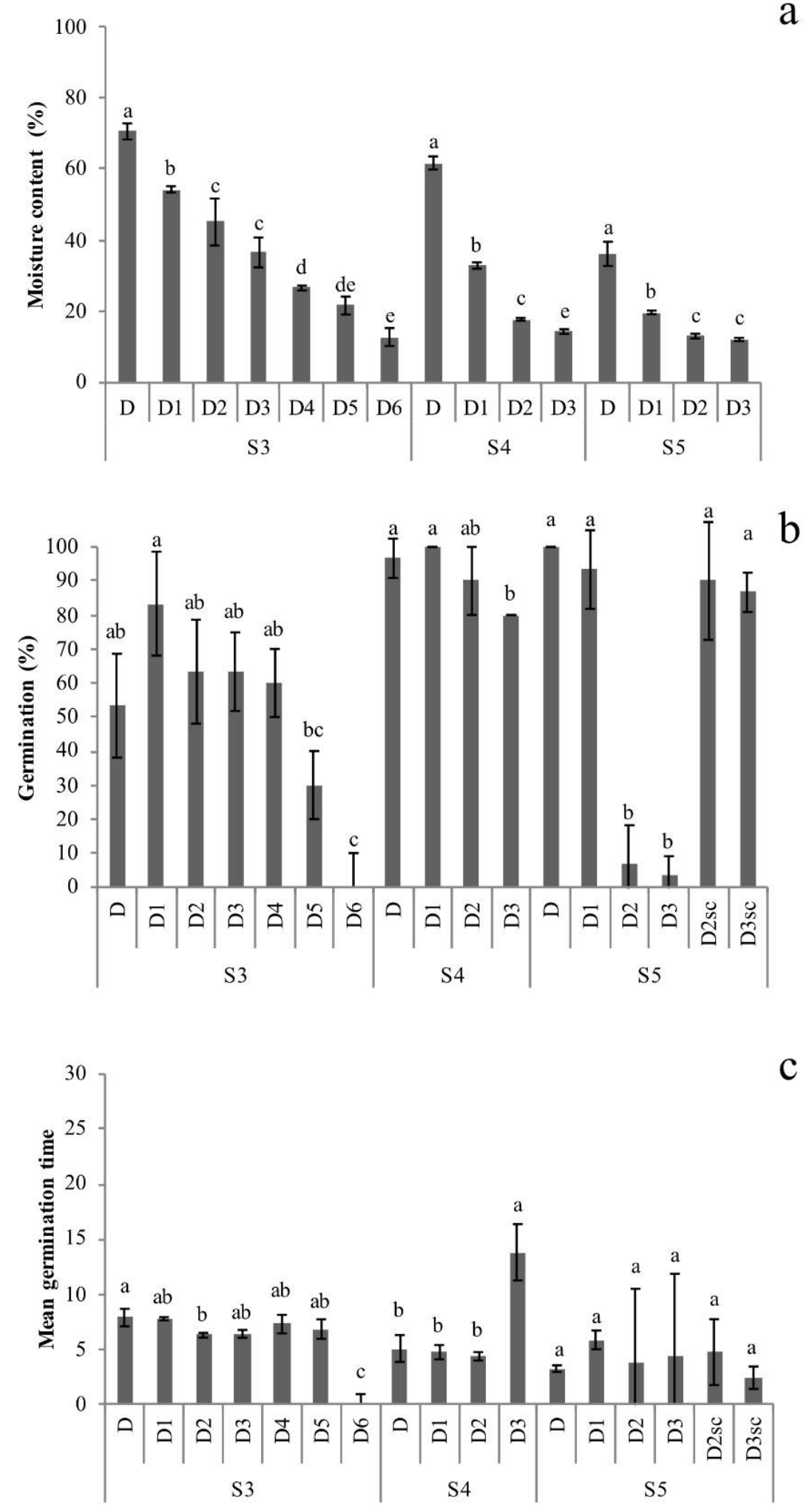

Columns with the same letter within each maturity stage represent value that do not differ from each other by the Tukey test (5\%). D2sc and D3sc: scarified seeds; D: intact seeds.

Figure 2. Moisture content (a), germination (b), and mean germination time (c) of immature seeds of Stage 3 (S3), Stage 4 (S4), and Stage 5 (S5) of Erythrina speciosa collected in 2014 under six levels of drying (D1, D2, D3, D4, D5, and D6). 

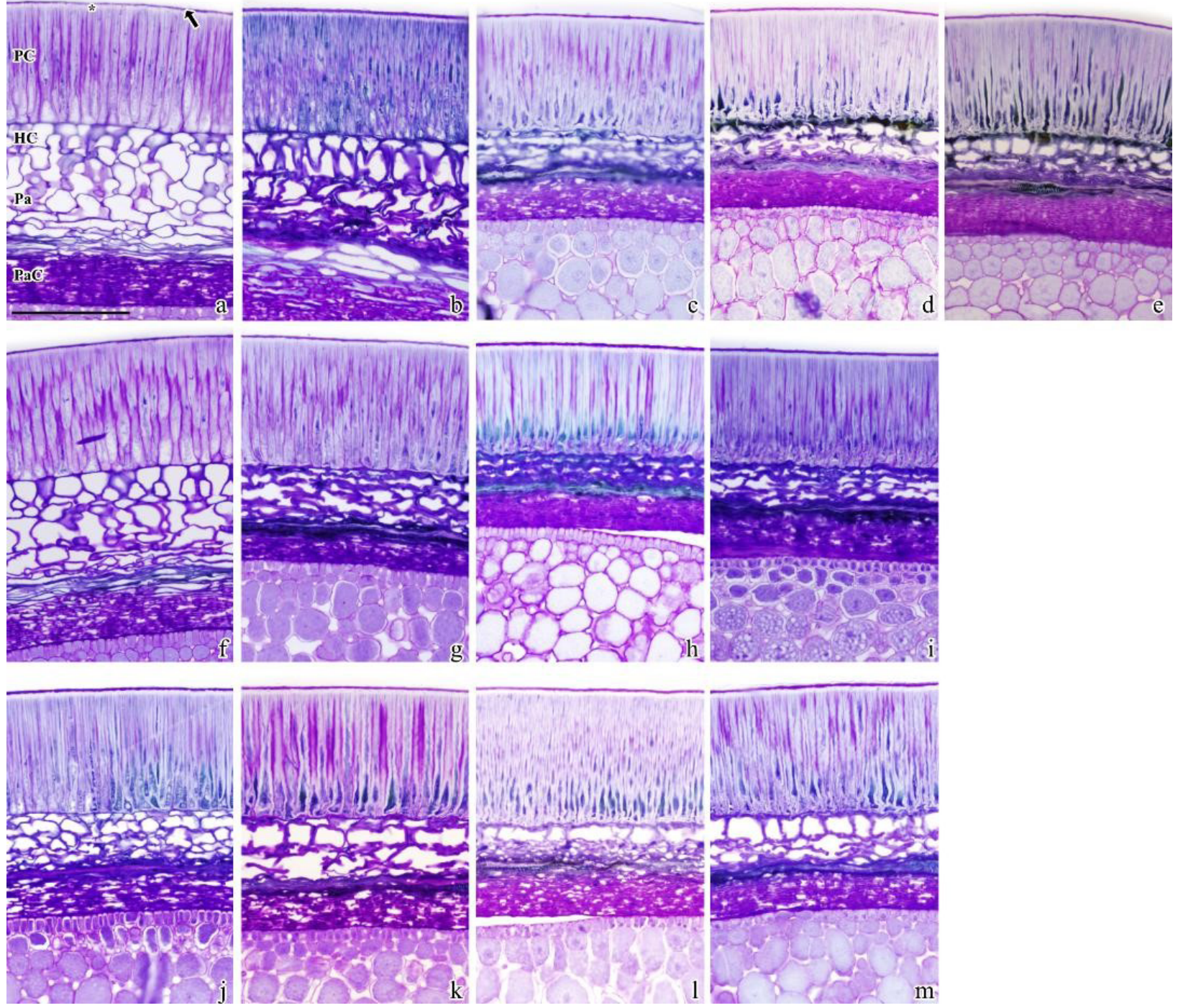

PC: palisade cells; HC: hourglass cells; Pa: parenchyma; PaC: collapsed parenchyma.

$\rightarrow$ : cuticle.

*: light line.

Scale: $100 \mu \mathrm{m}$.

Figure 3. Transversal section of the testa of intact immature seeds of Erythrina speciosa collected in 2013 in Stage 3 (a, $b, c, d, e)$, Stage $4(f, g, h, i)$, and Stage $5(j, k, l, m)$, without drying $(a, f, j)$, or dried to the first $(b, g, k)$, second $(c, h, l)$, third $(d, i, m)$, and fourth (e) levels.

The only tissue present in the seed testa that exhibited differences correlated with drying was the parenchyma. In S3 and S4 in the seeds of 2013, there was reduction in height consonant with reduction in seed moisture content. The parenchyma did not exhibit a height reduction in 55 in either year, possibly because the water removed during drying was in the cotyledons.

The results of germination before and after the drying of S3 and S4 seeds of 2013 and 2014 showed the proximity between the events of acquiring desiccation tolerance (DT) and the onset of dormancy by seed coat water impermeability (SCWI) when placed under drying. Considering that in orthodox seeds (tolerant to desiccation) moisture content is directly associated with the degree of seed maturation (Barbedo et al., 2013), the seeds of S3 of the two years could be in degrees of maturity quite near each other, because they exhibited the same moisture content (70\%). However, those of 2013 were tolerant to desiccation, but not those of 2014. The S4 seeds, also through moisture content, show a small 
variation in degree of maturation from 2013 to 2014, the former a little more mature than the latter (moisture content of $50 \%$ for 2013 and $60 \%$ for 2014, Figures 1 a and $2 a$ ). Although both already had DT, this difference was enough so that the seeds of 2013 acquired SCWI after drying, but not those of 2014 (Figures $1 \mathrm{~b}$ and 2b).

These variations within the same species may have occurred as a result of the environmental conditions in which the seeds developed, as indicated by Barbedo (2018). Germination differences in seeds coming from the same location but from different years are expected since the climate conditions the mother plant is exposed to can have an effect on maturation and vigor. E. speciosa seeds exhibited differences in SCWI, showing the effect of climate conditions both on the onset of SCWI and on the sensitivity of seeds to breaking this dormancy (Molizane et al., 2018). At any rate, the results of moisture content and germination in the present study confirm that immature seeds of $E$. speciosa can become impermeable, just as was observed by Gama-Arachchige et al. (2011) in Geranium carolinianum seeds.

The results of DT and SCWI in seeds of different ages and different years suggest the need for a minimum level of development so that seeds can independently develop the ability to germinate, tolerate desiccation, and establish seed coat impermeability. The seeds of S3 and S4 of 2014 did not achieve minimum development to tolerate drying or to develop SCWI, even though the seeds exhibited morphological and anatomical traits and moisture contents similar to those of 2013. Germination capacity and desiccation tolerance are not always acquired at the same time, and neither are desiccation tolerance and longevity (Leprince et al., 2017).
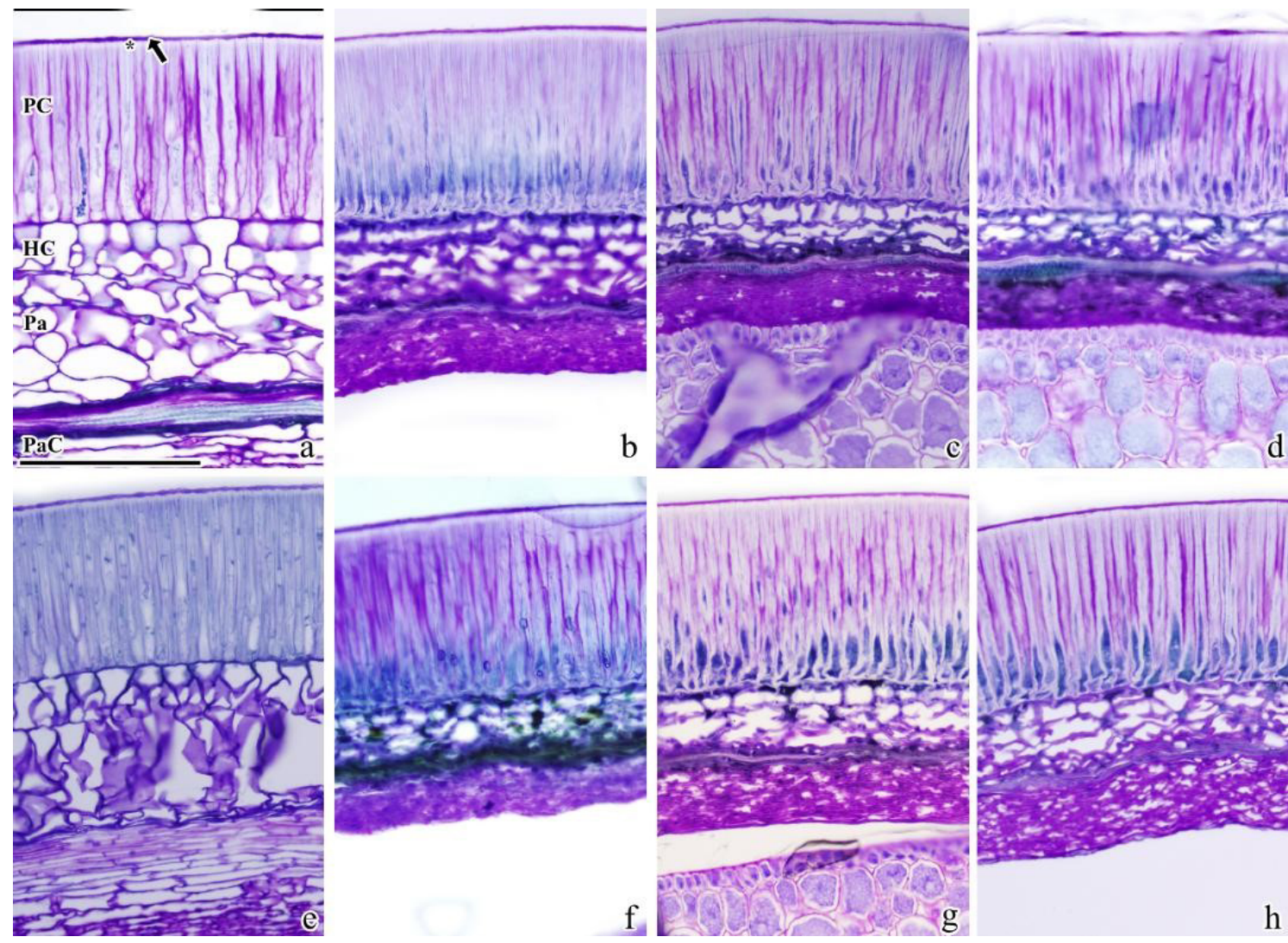

PC: palisade cells; HC: hourglass cells; Pa: parenchyma; PaC: collapsed parenchyma. $\rightarrow$ : cuticle.

*: light line.

Scale: $100 \mu \mathrm{m}$.

Figure 4. Transversal section of the testa of intact immature seeds of Erythrina speciosa collected in 2014 in Stage 4 (a, $b, c, d)$ and Stage $5(e, f, g, h)$, without drying $(a, e)$, or dried to the first $(b, f)$, second $(c, g)$, or third $(d, h)$ level. 

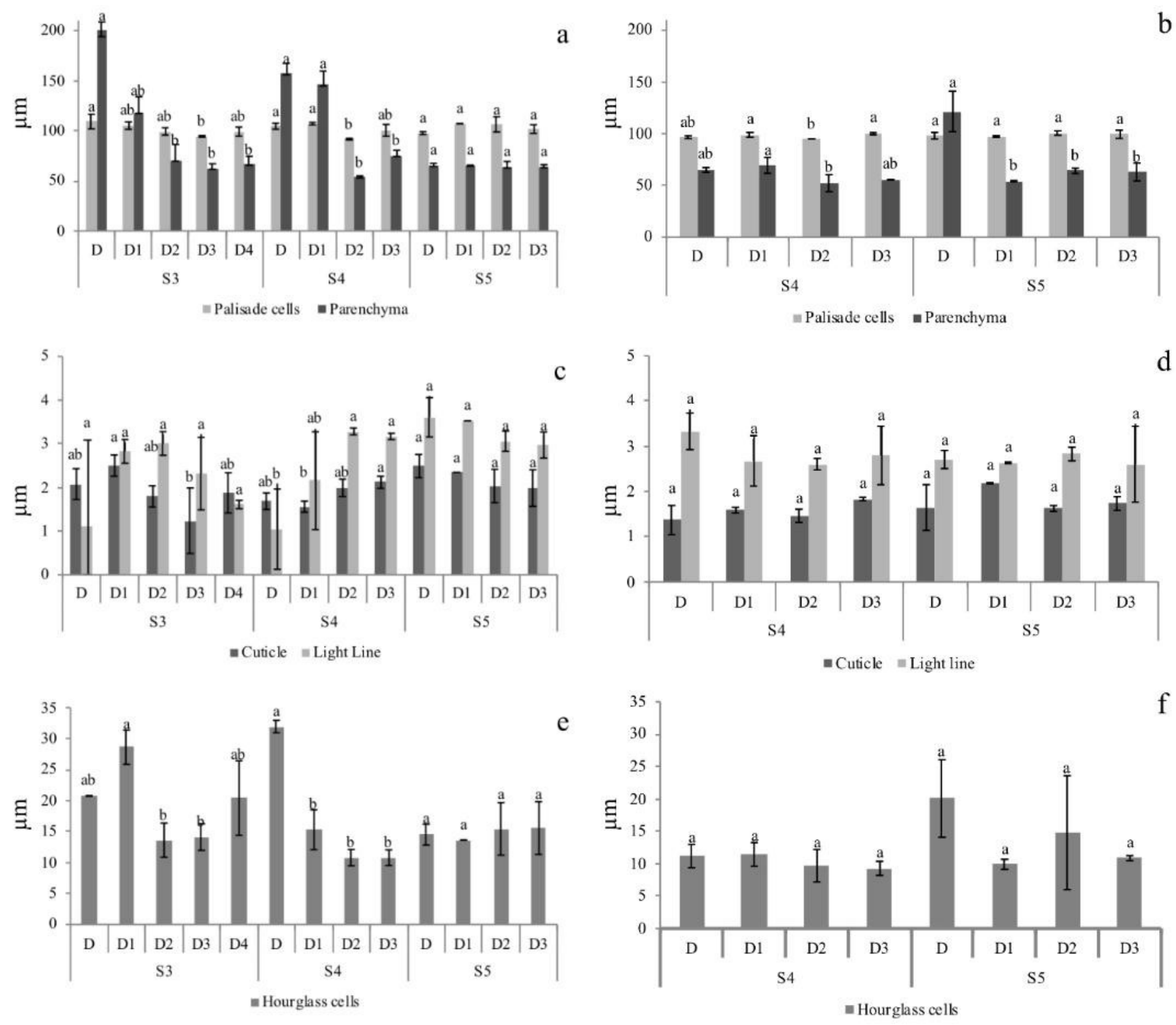

Figure 5. Measurements of tickness of the layers of palisade cells and parenchyma cells $(a, b)$, cuticle and light line (c, d), and hourglass cells (e, f) of the testa of Erythrina speciosa in intact immature seeds collected in 2013 (a, c, e) and 2014 (b, d, f) and artificially dried.

Barbedo et al. (2013) cite dormancy as a factor that extends seed longevity, as was also observed by Brancalion et al. (2010). In addition, Barbedo et al. (2013) suggest that the degree of dormancy, as well as the development of desiccation tolerance, is strongly affected by climatic conditions during maturation. This was observed in the present study with $E$. speciosa seeds produced in different years, which had different capacities for surviving drying and different degrees of dormancy. Richard et al. (2018) likewise observed a relationship between seed origin and dormancy in Desmanthus virgatus; the seeds coming from arid locations had a thicker seed coat and higher level of physical dormancy. Nevertheless, the author also suggests that biochemical analyses should be conducted on the species to confirm these observations.

The seed coat protects the embryo from injuries and regulates exchanges of gases and water between the embryo and the environment. Some cell layers present in the seed coat are considered to signal its impermeability. The seed 
coat of the immature seed in the present study had the same cell layers as the mature seeds observed by Molizane et al. (2018). Figures 3 and 4 show the layers of the palisade cells (PC) and the presence of the light line $(*)$ in the upper part of the cells near the cuticle (arrow). The cuticle and PC in Ormosia paraenses Ducke, for example, were considered to be associated with SCWI (Silva et al., 2018). The seed coat of E. speciosa also had hourglass cells (HC), a layer of parenchymal cells $(\mathrm{Pa})$, and collapsed parenchyma cells $(\mathrm{PaC})$. Many authors consider that this set of structures indicates the presence of seed coat impermeability in mature seeds (Manning and Van Staden, 1985; Lazarević et al., 2017).

In the treatments of induction of SCWI by drying, there was reduction in the thickness of the parenchyma and of the collapsed parenchyma. It was possible to differentiate the two types of parenchyma found in Erythrina seeds, but this differentiation cannot be made after the drying treatments. The parenchyma was the only tissue that showed statistical differences in its measurements related to induction from drying (Figures $5 a$ and $5 b$ ).

In addition, various authors indicate that the light line present in the palisade cells and in the hilum may also signal the onset of physical dormancy. Manning and Van Staden (1985) describe the light line as being a hydrophobic zone composed of suberin and cellulose, which leads to light refraction when observed in the microscope. The authors furthermore describe that the light line in Papilionoideae is located near the cuticle, but that in Mimosoideae and Caesalpinioideae it can be observed in the center of the palisade layer. However, the relationship between the presence of the light line and SCWI is controversial (Ferreira et al., 2011; Smýkal et al., 2014).

The seeds in this study show that even in immature seeds of the three stages of 2013 (Figures 3a, 3f, and 3j) and the two stages of 2014 (Figures 4a and 4e) analyzed, without drying, the light line was evident, but without changes in its thickness. Therefore, it was not possible to establish a relationship of this structure with the onset of SCWI. Chai et al. (2016) observed a relationship between the light line, together with the cuticle, and the onset of SCWI. Unlike that observation, as well as the observation made by Silva et al. (2018) for Ormosia paraenses, the measurements observed in the cuticle present above the layer of palisade cells in the seeds of E. speciosa in the present study did not show significant changes related to the onset of dormancy or to induction from drying. All the treatments in the two years of collection had a visible cuticle (Figures 3 and 4); therefore, the presence of the cuticle and light line for this species is not related to dormancy.

There were no changes in the layer of the palisade cells in the seeds of the immature stages before and after drying (Figures 3, 4, 5a, and 5b). Therefore, changes in this cell layer also appear not to be related to the onset of SCWI, unlike that observed by Silva et al. (2018) in Ormosia paraenses. In Desmanthus virgatus changes were found in the measurements of the palisade cells according to the year and location of collection (Richard et al., 2018). In E. speciosa of the present study, differences in the thickness of the testa in different years of collection were not observed.

Thus, the anatomical observations and the measurements of the seed coat in this study did not identify changes during induction of SCWI by drying that would confirm the relationship of dormancy with the palisade cells, light line, and the cuticle, as was observed in seeds of Glycine max and Vicia sativa (Harris, 1987; Chai et al., 2016). Therefore, for E. speciosa, SCWI may be related to biochemical differences in the testa of seeds brought about by environmental conditions, as observed in D. virgatu seeds studied by Vijayambika et al. (2011).

\section{CONCLUSIONS}

Drying of immature seeds of Erythrina speciosa can induce the onset of dormancy as long as a minimum level of maturity has been reached. Anatomical changes are not necessarily associated with the onset of this dormancy.

\section{ACKNOWLEDGMENTS}

The authors thank the Graduate Studies Program in Plant Biodiversity and Environment from Botanic Institute for the opportunity granted to the first author for doctoral studies; to the Conselho Nacional de Desenvolvimento Cientifico e Tecnológico (CNPq) for the doctoral scholarship granted to D.M. Molizane; and to the Parque Cultural Catavento for allowing seed collection. 


\section{REFERENCES}

BARBEDO, C.J. A new approach towards the so-called recalcitrant seeds. Journal of Seed Science, v.40, n.3, p.221-236, 2018. http:// www.scielo.br/pdf/jss/v40n3/2317-1545-jss-40-03-221.pdf

BARBEDO, C.J.; CENTENO, D.C.; FIGUEIREDO-RIBEIRO, R.C.L. Do recalcitrant seeds really exist? Hoehnea, v.40, n.4, p.583-593, 2013. http://www.scielo.br/pdf/hoehnea/v40n4/01.pdf

BASKIN, J.M.; BASKIN, C.C. Evolutionary considerations of claims for physical dormancy-break by microbial action and abrasion by soil particles. Seed Science Research, v.10, n.4, p.409-413, 2000. https://doi.org/10.1017/S0960258500000453

BRANCALION, P.H.S.; NOVEMBRE, A.D.L.C.; RODRIGUES, R.R.; MARCOS-FILHO, J. Dormancy as exaptation to protect mimetic seeds against deterioration before dispersal. Annals of Botany, v.105, p.991-998, 2010. https://www.ncbi.nlm.nih.gov/pmc/articles/ PMC2876011/pdf/mcq068.pdf

BRASIL. Ministério da Agricultura, Pecuária e Abastecimento. Regras para análise de sementes. Ministério da Agricultura, Pecuária e Abastecimento. Secretaria de Defesa Agropecuária. Brasília, DF: MAPA/ACS, 2009. 395p. https://www.abrates.org.br/files/ regras_analise_de_sementes.pdf

CHAI, M.; ZHOU, C.; MOLINA, I.; FU, C.; NAKASHIMA, J.; LI, G.; ZHANG, W.; PARK, J.; TANG, Y.; JIANG, Q.; WANG, Z.Y. A class II KNOX gene, KNOX4, controls seed physical dormancy. Proceedings of the National Academy of Sciences, v.113, n.25, p.6997-7002, 2016. https://www.pnas.org/content/pnas/113/25/6997.full.pdf

FERREIRA, N.R.; FRANKE, L.B.; MOÇO, M.C.C. Estudos morfo-anatômicos relacionados à dormência em sementes de Adesmia tristis Vogel (Fabaceae). Revista Brasileira Sementes, v.33, n.3, p.447-453, 2011. http://www.scielo.br/pdf/rbs/v33n3/07.pdf

GAMA-ARACHCHIGE, N.S.; BASKIN, J.M.; GENEVE, R.L.; BASKIN, C.C. Acquisition of physical dormancy and ontogeny of the micropyle-water-gap complex in developing seeds of Geranium carolinianum (Geraniaceae). Annals of Botany, v.108, n.1, p.51-64, 2011. https://doi.org/10.1093/aob/mcr103

HARRIS, W.M. Comparative ultrastructure of developing seed coats of "hard-seeded" and "soft-seeded" varieties of soybean, Glycine $\max$ (L.) Merr. Botanical Gazette, v.148, n.3, p.324-331, 1987. https://www.jstor.org/stable/2995350?seq=1\#metadata_ info_tab_contents

HAY, F.R.; SMITH, R.D.; ELLIS, R.H.; BUTLER, L.H. Developmental changes in the germinability, desiccation tolerance, hardseededness and longevity of individual seeds of Trifolium ambiguum. Annals of Botany, v.105, n.6, p.1035-1052, 2010. https://doi.org/10.1093/ aob/mcq037

HELL, A.; KRETZSCHMAR, F.S.; SIMÕES, K.; HEYER, A.G.; BARBEDO, C.J.; BRAGA, M.R.; CENTENO, D.C. Metabolic changes on the acquisition of desiccation tolerance in seeds of the Brazilian native tree Erythrina speciosa. Frontiers in Plant Science, v.10, n.1356, 2019. https://doi.org/10.3389/fpls.2019.01356

JAYASURIYA, K.M.G.G.; BASKIN, J.M.; GENEVE, R.L.; BASKIN, C.C. Morphology and anatomy of physical dormancy in Ipomoea lacunosa: identification of the water gap in seeds of Convolvulaceae (Solanales). Annals of Botany, v.100, n.1, p.13-22, 2007a. https://doi.org/10.1093/aob/mcm070

JAYASURIYA, K.M.G.G.; BASKIN, J.M.; GENEVE, R.L.; BASKIN, C.C. Seed development in Ipomoea lacunosa (Convolvulaceae), with particular reference to anatomy of the water gap. Annals of Botany, v.100, p.459-470, 2007b. https://www.ncbi.nlm.nih.gov/pmc/ articles/PMC2533602/pdf/mcm137.pdf

JOHANSEN, D.A. Plant microtechnique. New York: McGraw-Hill, 1940. 487p.

LAMARCA, E.V.; PRATAVIERA, J.S.; BORGES, I.F.; DELGADO, L.F.; TEIXEIRA, C.C.; CAMARGO, M.B.P.; FARIA, J.M.R.; BARBEDO, C.J. Maturation of Eugenia pyriformis seeds under different hydric and thermal conditions. Anais da Academia Brasileira de Ciências, v.85, n.1, p.223-233, 2013. http://www.scielo.br/pdf/aabc/v85n1/0001-3765-aabc-85-01-223.pdf

LAZAREVIĆ, J.; ZORIĆ, L.; KARAGIĆ, D.; MILOŠEVIĆ, B.; KARANOVIĆ, D.; MILIĆ, D.; TEPIĆ, A.; LUKOVIĆ, J. Anatomical and micromorphological characteristics of the seed coat of field pea (Pisum sativum L.) genotypes in relation to cracks and damage of seeds. Archives of Biological Sciences, v.69, n.3, p.503-512, 2017. http://serbiosoc.org.rs/arch/index.php/abs/article/view/698/pdf_87 
LEPRINCE, O.; PELLIZZARO, A.; BERRIRI, S.; BUITINK, J. Late seed maturation: drying without dying. Journal of Experimental Botany, v.68, n.4, p.827-841, 2017. https://doi.org/10.1093/jxb/erw363

LIMA, H.C.; MARTINS, M.V. Erythrina. In: Lista de Espécies da Flora do Brasil. Jardim Botânico do Rio Janeiro, 2014. http:// floradobrasil.jbrj.gov.br/jabot/floradobrasil/FB29677

MANNING, J.C.; VAN STADEN, J. The development and ultrastructure of the testa and tracheid bar in Erythrina lysistemon Hutch. (Leguminosae: Papilionoideae). Protoplasma, v.129, p.157-167, 1985. https://link.springer.com/content/ pdf/10.1007\%2FBF01279913.pdf

MELLO, J.I.O.; BARBEDO, C.J.; SALATINO, A.; FIGUEIREDO-RIBEIRO, R.C.L. Reserve carbohydrates and lipids from the seeds of four tropical tree species with different sensitivity to desiccation. Brazilian Archives of Biology and Technology, v.53, n.4, p.889-899, 2010. http://www.scielo.br/pdf/babt/v53n4/v53n4a19.pdf

MOLIZANE, D.M.; JULIO, P.G.S.; CARMELLO-GUERREIRO, S.M.; BARBEDO, C.J. Physical, physiological and anatomical changes in Erythrina speciosa Andrews seeds from different seasons related to the dormancy degree. Journal of Seed Science, v.40, n.3, p.331341, 2018. http://www.scielo.br/pdf/jss/v40n3/2317-1545-jss-40-03-331.pdf

NAKAGAWA, J.; CAVARIANI, C.; MARTINS, C.C.; COIMBRA, R.D.A. Intensidade de dormência durante a maturação de sementes de mucuna-preta. Revista Brasileira de Sementes, v.29, n.1, p.165-170, 2007. http://www.scielo.br/pdf/rbs/v29n1/23.pdf

O'BRIEN, T.P.; FEDER, N.; MCCULLY, M.E. Polychromatic staining of plant cell walls by toluidine blue. Protoplasma, v.59, p.367-373, 1964. https://link.springer.com/content/pdf/10.1007\%2FBF01248568.pdf

RICHARD, G.A.; ZABALA, J.M.; CERINO, M.C.; MARINONI, L.D.R.; BEUTEL, M.E.; PENSIERO, J.F. Variability in hardseededness and seed coat thickness of three populations of Desmanthus virgatus (Fabaceae, Mimosoideae). Grass and Forage Science, v.73, p.938946, 2018. https://onlinelibrary.wiley.com/doi/epdf/10.1111/gfs.12385

SILVA, B.M.S.; SILVA, C.O.; MÔRO, F.V.; VIEIRA, R.D. Seed anatomy and water uptake and their relation to seed dormancy of Ormosia paraensis Ducke. Journal of Seed Science, v.40, n.3, p.237-245, 2018. http://www.scielo.br/pdf/jss/v40n3/2317-1545jss-40-03-237.pdf

SMÝKAL, P.; VERNOUD, V.; BLAIR, M.W.; SOUKUP, A.; THOMPSON, R.D. The role of the testa during development and in establishment of dormancy of the legume seed. Frontiers in Plant Science, v.5, p.1-19, 2014. https://doi.org/10.3389/fpls.2014.00351

VIJAYAMBIKA, C.; JEGADEESAN, M.; GANTHI, A.S. Comparative anatomical studies on seeds of Mucuna Adans. and Canavalia DC. species. Indian Journal of Natural Products and Resources, v.2, n.1, p.81-87, 2011. http://nopr.niscair.res.in/ bitstream/123456789/11545/1/IJNPR\%202(1)\%2081-87.pdf use, distribution, and reproduction in any medium, provided the original work is properly cited. 